\title{
Effect of Stress Ratio and Notch on Fatigue Strength of CP Titanium
}

\author{
by
}

\section{Toshiaki IWATA*}

Titanium alloys such as Ti-6Al-4V are used worldwide in the field of aerospace, and the applied results are abundant, and the data are accumulated as structural members. On the other hand, commercial pure (CP) titanium which is cheaper than the alloys is widely used in the field of general industry in Japan because it is superior to seawater corrosion resistance and biocompatibility. However, CP titanium has anisotropy to consist of only hcp crystal structure, therefore, the strength data are insufficient because of the short history as structural materials, and an unidentified part of the mechanical materials properties is remaining. In this study, the effect of mean stress and stress concentration on fatigue strength of $\mathrm{CP}$ titanium was evaluated for the application range expansion of $\mathrm{CP}$ titanium which has a superior characteristic as structural members in the field of marine. As the result, the following conclusions were provided. Endurance limit of longitudinal (L) direction was $80-84 \%$ of endurance limit of transverse $(\mathrm{T})$ direction on smooth specimens, on the other hand, no significant difference was found in endurance limit of both directions on notched specimens. It is necessary to apply at least $S_{a}-0.5 S_{u}$ line to design the safe side in CP titanium. Around $K_{t}=2$, the notch sensitivity factor of CP titanium in T-direction is larger than that of carbon steel and it in L-direction is smaller than that of carbon steel. On the other hand, in $K_{t}=3.77$, it in L-direction is at the same level as that of S15C or $\mathrm{S} 35 \mathrm{C}$ and it in T-direction is at the same level as that of S45C. In the design of the welding structure composed by CP Grade2 titanium which is the nearest to mechanical strength of ship's classifications mild steel, it seems that the design fatigue strength of the steel welding structure is applicable.

\section{Key words}

Commercial pure titanium, Hexagonal close-packed, Anisotropy, Fatigue strength, Stress ratio, Notched strength, Endurance limit diagrams

\section{1 緒 言}

世界的には，強度・延性・じん性のバランスに優れた Ti-6Al-4V などのチタン合金が, 高比強度化の要求が特に 高い航空宇宙分野で利用され，構造部材としての実績が 豊富でデータが蓄積されている。1)，2）一方我が国では， 海水耐食性や生体親和性に優れ，合金と比較して安価な 純チタンが一般産業分野でプラントや熱交換機などに広 く利用されているが, hep 構造と bcc 構造の 2 相が存在す る Ti-6Al-4V とは異なり, hcp 構造のみから成り異方性が ある純チタンは，構造材料として歴史は浅く，強度デー タが不十分で機械的材料特性に不明な部分が残されてい る.

海水耐食性に優れた純チタンは，船舶用材料として適 しており, 漁船・ヨットの船体構造部材や, 排気管・海 水冷却管など㛜しい腐食環境の非構造部材や艤装品とし て，2000 年頃から使用され始めていた。チタン合金も含 めチタン溶接構造設計法が確立されていなかったため, 著者は，工業用純チタン 2 種を船舶用軟鋼の機械的強度 に最も近い船舶用新材料として, 過去に工業用純チタン 2 種から成る船体構造主要三継手（突合継手，荷重非伝達
型十字継手，角回し継手）の疲労強度評価を報告した。 ${ }^{3)}$ しかしながら, 純チタンは, 溶接構造材料の母材として の疲労強度データが不十分である。

そこで, 本研究では, 海洋分野で構造部材として優れ た特性を持つ純チタンの応用範囲拡大のため, 純チタン の疲労強度に及ぼす平均応力と応力集中の影響を評価し た.

\section{1 供試材}

2 実験方法

供試材は工業用純チタン 2 種熱間圧延板 JIS H4600 TP340H を使用した. Table 1 に, 供試材の化学成分のミル シートの值を示す。電界放射型走査型電子顕微鏡 （FE-SEM）の結晶方位解析装置（EBPS）で観察したミ クロ組織および結晶方位分布を, Fig. 1 に示す.

L-LT 面は, 板の表面を圧延方向 (L:Longitudinal direction)

Table 1 Chemical composition (wt \%).

\begin{tabular}{|c|c|c|c|c|c|c|}
\hline & $\mathrm{N}$ & $\mathrm{C}$ & $\mathrm{H}$ & $\mathrm{Fe}$ & $\mathrm{O}$ & $\mathrm{Ti}$ \\
\hline $\begin{array}{c}\text { Inspection } \\
\text { Certification }\end{array}$ & 0.00 & 0.00 & 0.001 & 0.04 & 0.10 & $\mathrm{Bal}$ \\
\hline
\end{tabular}

$\dagger$ 原稿受理 平成29年 5月10日 Received May 10, 2017 @2017 The Society of Materials Science, Japan

* 国立研究開発法人 海上·港湾·航空技術研究所 海上技術安全研究所 $\bar{\top}$ 181-0004 東京都三鷹市新川

National Maritime Research Institute, National Institute of Maritime, Port and Aviation Technology, Shinkawa, Mitaka, Tokyo 181-0004. 
に見た組織である．L-ST 面は板厚面を L 方向に見た組織 であり，圧延と直角方向（T:Transverse direction）に採取 した試験片の断面である. LT-ST 面は板厚面を T 方向に見 た組織であり，L方向に採取した試験片の断面である. 粒 径の分布は概ね一様であった。結晶方位の分布は, L-ST 面と LT-ST 面は類似し， [0001]方向が主体的であるのに 対して, L-LT 面では, [0001]方向の割合が若干少なくな るに伴い[1010]方向がわずかに増えているが，L-ST 面並 びに LT-ST 面との違いはわずかであった. 峯ら ${ }^{4), 5) に よ ~}$ り, hcp 金属である純チタンでも，き裂先端で交差する 2 つのすべりの交互の活動に基づいてき裂が進展するが,

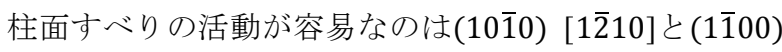

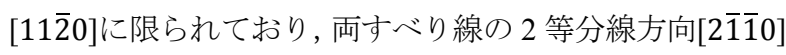
が最も進展し安く, すべり面に直交する $[000 \overline{1}]$ 方向が最も 進展しにくいと報告されている. Fig. 1 からは, 粒径の分
布と結晶方位の分布のどちらも, $\mathrm{L}$ 方向試験片断面と $\mathrm{T}$ 方向試験片断面では違いがほとんど見受けられないので, 伝ぱ寿命には差はあまりないものと考えられる. Table 2 に, JIS 5 号引張試験片による静的強度試験から得られた 供試材の機械的特性を，ミルシートの值並びに規格值と 併せて示す. 更に, 表中に鋼船規則で規定される船舶用 軟鋼の機械的強度も併せて示寸. 現行の鋼船規則の強度 規定に準じた材料ほど，新材料として承認される際の制 約が少なくなると考えられる，そこで，工業用純チタン のうち 2 種を船舶用軟鋼に置き換わる材料として選定し た.

\section{2 試験片}

平滑材試験片の形状を Fig. 2 に, 切欠試験片を Fig. 3 に 示す. JIS5 号引張試験片と共に, 供試材から L 方向およ び $\mathrm{T}$ 方向に採取した. 平滑材試験片では, 低応力での掴

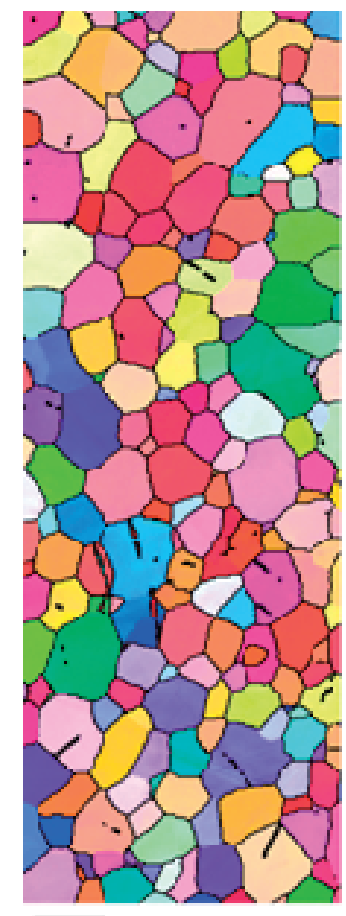

$40.00 \mathrm{~mm}=40$ steps

L-LT

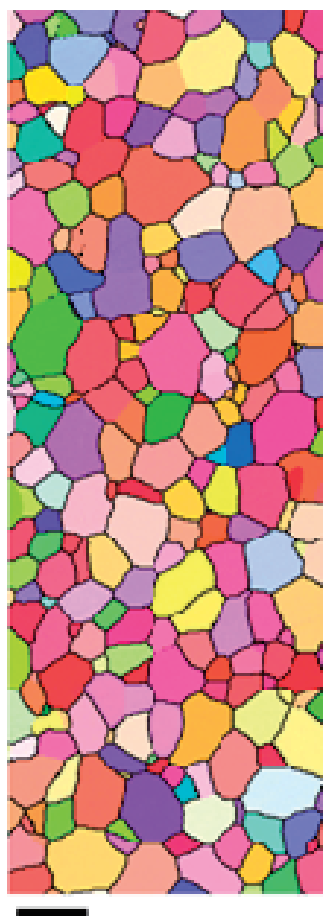

$4 \overline{0} .00 \mathrm{~mm}=40 \mathrm{steps}$

L-ST

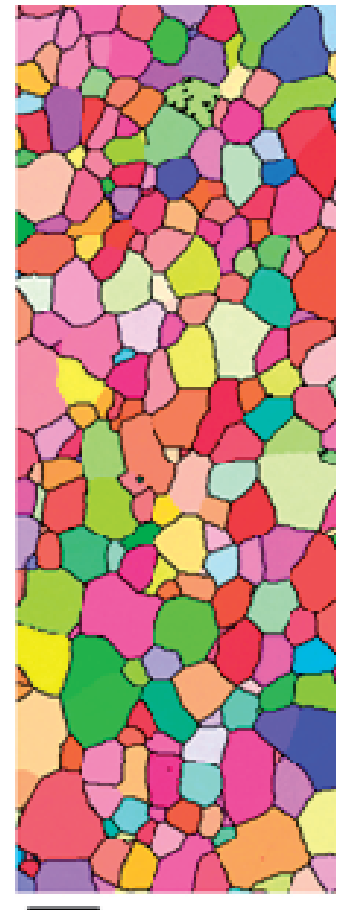

$40.00 \mathrm{~mm}=40$ steps

LT-ST

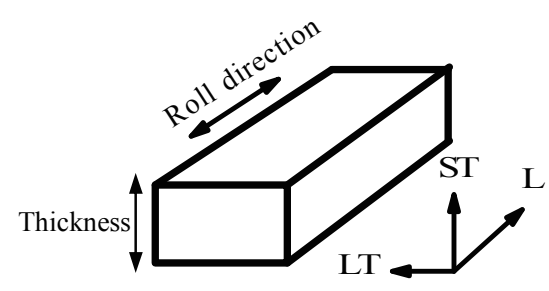

Gray Scale Map Type: <none>

Color Coded Map Type: Inverse Pole Figure Titanium (Alpha)

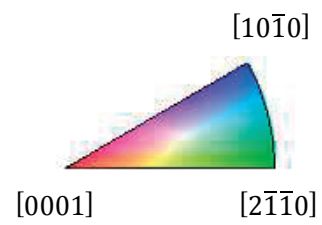

Boundaries: Rotation Angle $\frac{\text { Min }}{15^{\circ}} \frac{\text { Max }}{180^{\circ}} \frac{\text { Fraction }}{0.433}$

*For statistics - any point pair with misorientation exceeding $2^{\circ}$ is considered a boundary

Fig.1 Microstructure and crystal orientation distribution.

\begin{tabular}{|c|c|c|c|c|c|c|c|c|c|c|c|}
\hline & Direction & $\begin{array}{c}\text { Modulus of } \\
\text { longitudinal } \\
\text { elastisity }\end{array}$ & $\begin{array}{l}\begin{array}{c}\text { Peoportional } \\
\text { limit stress }\end{array} \\
\end{array}$ & $\begin{array}{l}0.2 \% \\
\text { Proof } \\
\text { stress } \\
\end{array}$ & $\begin{array}{c}\text { Maximum } \\
\text { tensile } \\
\text { stress } \\
\end{array}$ & $\begin{array}{c}\text { Fracture } \\
\text { stress }\end{array}$ & $\begin{array}{c}\text { True } \\
\text { fracture } \\
\text { stress }\end{array}$ & $\begin{array}{l}\text { Yield } \\
\text { ratio }\end{array}$ & $\begin{array}{l}\text { Uniform } \\
\text { elongation }\end{array}$ & $\begin{array}{c}\text { Total } \\
\text { elongation }\end{array}$ & $\begin{array}{c}\text { Contraction } \\
\text { of area }\end{array}$ \\
\hline & & $E$ & $S_{e}$ & $S_{0.2}$ & $S_{u}$ & $S_{f}$ & $S_{t}$ & $S_{0.2} / S_{u}$ & $d_{u}$ & $d_{f}$ & $F$ \\
\hline & & $\mathrm{GPa}$ & \multicolumn{5}{|c|}{$\mathrm{MPa}$} & & \multicolumn{3}{|c|}{$\%$} \\
\hline \multicolumn{2}{|c|}{ JIS H4600 TP340 H } & & & $\geq 215$ & $340-510$ & & & & & $\geq 23$ & \\
\hline $\begin{array}{l}\text { Inspection } \\
\text { Certification }\end{array}$ & Transverse & & & 342 & 446 & & & & & 37 & \\
\hline \multirow{2}{*}{ Exp. Ave } & Longitudinal & 106 & 123 & 248 & 400 & 311 & 675 & 0.619 & 13.9 & 41.9 & 54.0 \\
\hline & Transverse & 118 & 201 & 337 & 415 & 287 & 748 & 0.812 & 7.36 & 45.7 & 61.7 \\
\hline \multicolumn{2}{|c|}{$\begin{array}{c}\text { Ship's Classifications } \\
\text { mild steel }\end{array}$} & & & $\geq 235$ & $400-520$ & & & & & $\geq 16$ & \\
\hline
\end{tabular}


み部からの破断を避けるため，最小断面幅の 2.5 倍を掴み 部幅とした．船舶構造は種々の形状を有し，溶接止端な どに切欠きがある。これらの形状や切欠きは，応力集中 係数 $K_{t}$ が 2 4 の試験片で模擬することができる. 本研究 では，切欠試験片の応力集中係数を， $K_{t}=2.0,2.93,3.77$ と した．切久部の最小断面の幅および切久深さは一定であ る。切欠部を含む平行部と $R$ 部は，エメリ一紙 800 番以 上に研磨した。

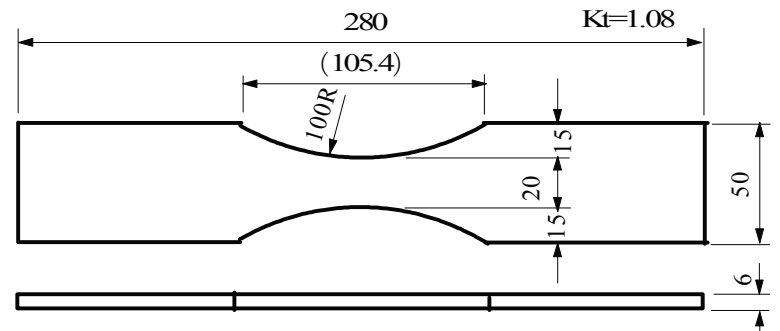

Fig.2 Configuration of smooth test specimen.

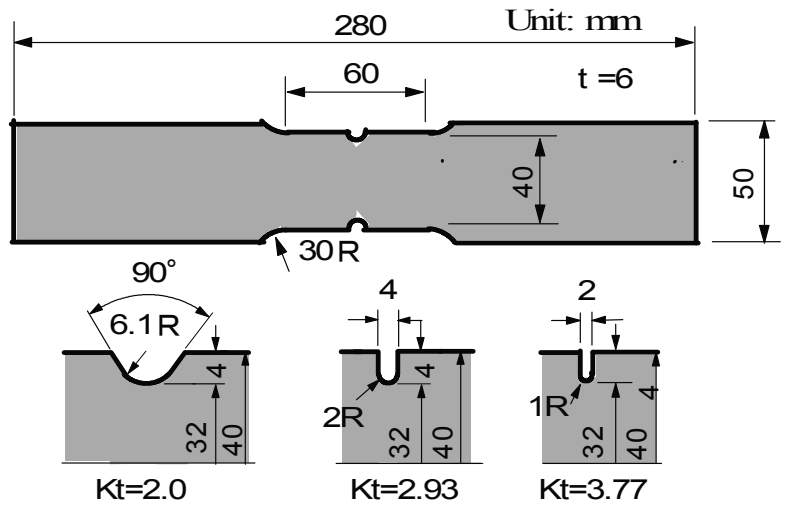

Fig.3 Configuration of notched test specimens.

\section{3 試験条件}

疲労試験は，油圧サーボ疲労試験機を用い正弦波の荷 重制御とした。試験温度は室温である。平板試験片のた め, 圧縮の際に座屈しないよう周波数は $1 \sim 5 \mathrm{~Hz}$ とした. 応力比は, 平滑材疲労試験は $R=-1,0,0.3$ の 3 条件, 切欠 き疲労試験は $R=0$ の 1 条件とした。

\section{3 実験結果と考察}

\section{1 疲労試験結果}

Fig. 4 に異なる応力比における公称応力範囲 $\Delta \mathrm{S}$ と破 断寿命 $N$ の関係を，Fig. 5 に異なる切欠形状における公 称応力範囲 $\Delta S$ と破断寿命 $N$ の関係を示す. なお, Fig. 5 における $K_{t}=1.08 \quad(R=0)$ の結果は, Fig. 4 における $R=0$ $\left(K_{t}=1.08\right)$ の結果を採用した. 勾配と定数は最小二乗法 により決定した。実線は 50\%生存確率線，点線は，実線 から $N$ の常用対数に対して 2 標準偏差減じて算出された 97.5\%生存確率線である. 工業用純チタンは, 鉄鋼やチ タン合金とは異なり，アルミニウム合金と同様に，明瞭 な $S-N$ 線図の水平折れ曲がりを示さず，切欠き疲労試験
では, 1000 万回以上で破断する試験片があった. そこで, 本研究では，500 万回を超えても水平折れ曲がりが不明 瞭な場合は，2000 万回まで試験を継続した. 破断した試 験片のうち最も低い公称応力範囲を破断下限公称応力 範囲とし，この破断下限公称応力範囲より高い公称応力 範囲で破断しなかった試験片は除外し，残りの破断しな かった試験片のうち最も高い公称応力範囲と破断下限 公称応力範囲の中間となる公称応力範囲を算出し，その 半分となる公称応力振幅 $\left(S_{a}=0.5 \Delta S\right)$ を疲労限度として 採用した.この結果, $S-N$ 線図の折れ曲がり点は, $7 \times 10^{5}$ $\sim 5 \times 10^{6}$ 回の範囲となった。

鋼材の疲労限度は引張強度に依存するのに対して, 工 業用純チタンでは, Table 2 で示される通り, L 方向と $\mathrm{T}$ 方向の引張強度は 4\%程度しか違いがないにも係わらず, Fig. 4 で示される通り, 同じ応力比で比較すると, L 方 向の疲労限度は $\mathrm{T}$ 方向の疲労限度の $80 \sim 84 \%$ あ゙あった。 これは，Table 2 で示される通り，L 方向の耐力は $\mathrm{T}$ 方向 の耐力の $74 \%$ 程度であり, 疲労限度に及ぼす異方性の影 響は，耐力に及ぼす異方性の影響よりはやや小さいが， 引張強度に及ぼす異方性の影響と異なっており，耐力の 相違が疲労限度に影響を及ぼしているためと考えられ る。

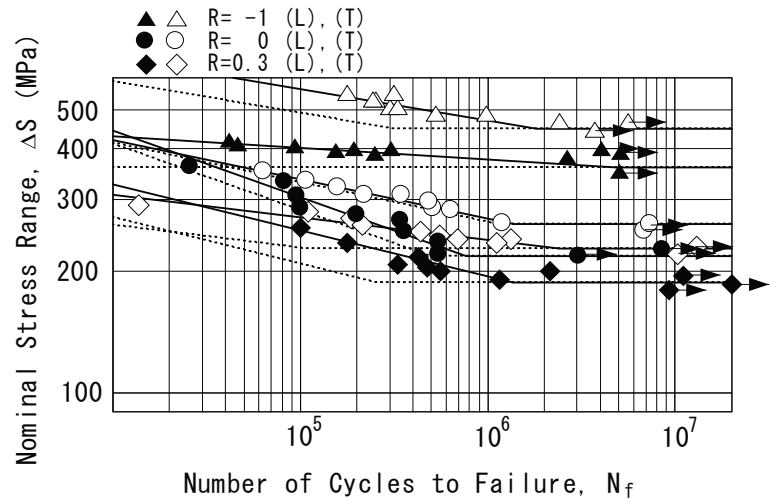

Fig.4 Relation between nominal stress range and number of cycles to failure in the different stress ratio.

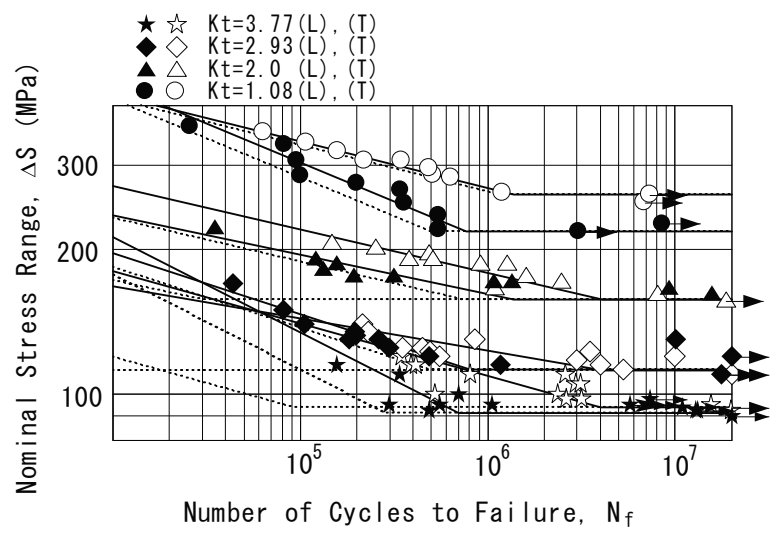

Fig.5 Relation between nominal stress range and number of cycles to failure in the different notch shape. 
Fig. 5 で示される通り，平滑材では L 方向の疲労強度は $\mathrm{T}$ 方向の疲労強度の $84 \%$ であり，切欠材でも， $S-N$ 曲線 傾斜部の有限寿命域では $\mathrm{L}$ 方向の疲労強度は $\mathrm{T}$ 方向の疲 労強度よりも低いのに対して, $\mathrm{L}$ 方向の疲労限度と $\mathrm{T}$ 方向に疲労限度には有意な差がなかった. Table 3 に切欠 き底の最大応力 (応力集中係数 $\times$ 疲労限度) $K_{t} S_{w}$ を示す. $\mathrm{L}$ 方向ではすべての切欠き材で $K_{t} S_{w}$ は $S_{0.2}$ 以上またはわ ずかに下であるが， $\mathrm{T}$ 方向では $K_{t} S_{w}$ は $S_{0.2}$ 以下またはわ ずかに上であり，切欠き材におけるき裂は，L方向では 鉄鋼材料と同様に塑性域の応力で発生するが， $\mathrm{T}$ 方向で は主に弾性域内の応力でき裂が発生しているといえる. よって, 弾性域内の応力で発生した $\mathrm{T}$ 方向切欠き材のき 裂も, $\mathrm{L}$ 方向の塑性域の影響を受け, 本研究で対象とし た範囲の切欠き材では，L方向の疲労限度と $\mathrm{T}$ 方向に疲 労限度には有意な差がなかったのではないかと考えら れる。また，Ti-6Al-4V 合金に対する林ら ${ }^{2)}$ の報告と異 なり, 工業用純チタンに対する藤井ら ${ }^{6)}$ の報告と同様に, 平滑材では $1 \times 10^{6}$ 回前後に $S-N$ 線図の折れ点が存在する が，切欠き材では特に L 方向において，折れ点が不明瞭 であった. よって, 平滑材と切欠き材の折れ点の繰り返 し数の違いは識別しにくいが， L 方向では有意差がなく $1 \times 10^{6}$ 回前後であり, $\mathrm{T}$ 方向では切欠き材は $4 \times 10^{6}$ 回前 後の長寿命側にシフトする傾向があるといえる. 藤井ら 6) の報告でも同様に，切欠き材では破断寿命の折れ点が 長寿命側にシフトする傾向が見て取れる. L 方向と $\mathrm{T}$ 方 向で傾向が異なるのは, L 方向の $0.2 \%$ 而力は異方性の影 響により $\mathrm{T}$ 方向より低く， T 方向では弾性域であっても $\mathrm{L}$ 方向では塑性域となり, 前述の通り $\mathrm{T}$ 方向切久き材で は弾性域内の応力で発生したき裂が，L 方向の塑性域の 影響を受けているためと考えられる。

Table 3 Maximum stress of notch root (MPa).

\begin{tabular}{|c|c|c|c|c|c|}
\hline Direction & $\begin{array}{c}0.2 \% \text { Proof } \\
\text { stress }\end{array}$ & \multicolumn{4}{|c|}{ Maximum stress of notch root } \\
\hline & $S_{0.2}$ & & \multicolumn{2}{|c|}{$K_{t} S_{w}$} & \\
\cline { 2 - 6 } & & $K_{t}=1$ & $K_{t}=2$ & $K_{t}=2.93$ & $K_{t}=3.77$ \\
\hline Longitudinal & 248 & 236 & 315 & 330 & 344 \\
\hline Transverse & 337 & 282 & 315 & 328 & 353 \\
\hline
\end{tabular}

\section{2 平均応力の影響評価}

疲労試験から得られた疲労限度を用い，Fig. 6 に L 方 向の疲労限度線図を，Fig. 7 に $\mathrm{T}$ 方向の疲労限度線図を 示す. 縦軸は公称応力振幅 $S_{a}$, 横軸は平均応力 $S_{m}$ であ る.一般に炭素鋼などの鋼材は, 実験点が $S_{a}-S_{t}$ 線図によ く近似しており，修正 Goodman 線図を用いれば安全側 の設計となる.7) これに対して，Fig. 6 およびFig. 7 で 示される通り，工業用純チタンでは， L 方向と $\mathrm{T}$ 方向の 両方向で，実験点が $R=0$ では Soderberg 則に， $R=0.3$ で は修正 Goodman 則に近似し，修正 Goodman 線図では, 危険側の設計となった。すなわち，工業用純チタンは， 鋼材よりも平均応力の影響が大きく, 平均応力が大きく なると共に Soderberg 線図〜修正 Goodman 線図の範囲で,
疲労限度が低下した. Fig. 6 および Fig. 7 に， $S_{u}$ を用い る修正 Goodman 線図に加えて，1/3S を用いる Goodman 線図と $1 / 2 S_{u}$ を用いる $S_{a}-0.5 S_{u}$ 線を併せて示す. 工業用純 チタンで安全側の設計とするには, 修正ではないオリジ ナルの Goodman 線図か, 少なくとも $S_{a}-0.5 S_{u}$ 線を用いる 必要がある。

一方，Ti-6Al-4V 合金では，竹内ら ${ }^{1)}$ により，106 回以 下の短寿命側で主に表面破壊であるが， $10^{5}$ 回 $5 \times 10^{6}$ 回の領域で $S-N$ 曲線は一度水平になり, $10^{6}$ 回以上の長 寿命側で主に内部破壊に移行すると報告されている。よ って, $10^{7}$ 回強度を疲労限度とすれば, 表面破壊が主体 となるため, 表面破壊特性に対する線図である修正 Goodman 線図からの予測は安全側となるが，10 8 回強度 を疲労限度とすると, 内部破壊の影響により, 修正 Goodman 則による予測が危険側となると示されている. Ti-6Al-4V 合金では，0.2\%耐力と引張強度は 5〜 7\%ほど しか違わないため, $10^{8}$ 回強度を疲労限度とすると, 内 部破壊の影響により，0.2\%耐力基準の Soderberg 則を用 いても危険側の予測となる。これに対して，工業用純チ タンでは，本研究で対象とした範囲においては, Ti-6Al-4V 合金とは異なり $10^{7}$ 回以下ではすべて表面破 壊で，内部破壊は確認されなかった。高尾ら ${ }^{8), 9)}$ は，工 業用純チタンのような hcp 結晶構造では, bcc や fcc とは 異なり，すべり系の数が非常に少なく，き裂発生条件を 満たす結晶が離散的に分布して存在しており，隣接する 結晶相互のすべりの塑性拘束効果が大きいため，き裂の

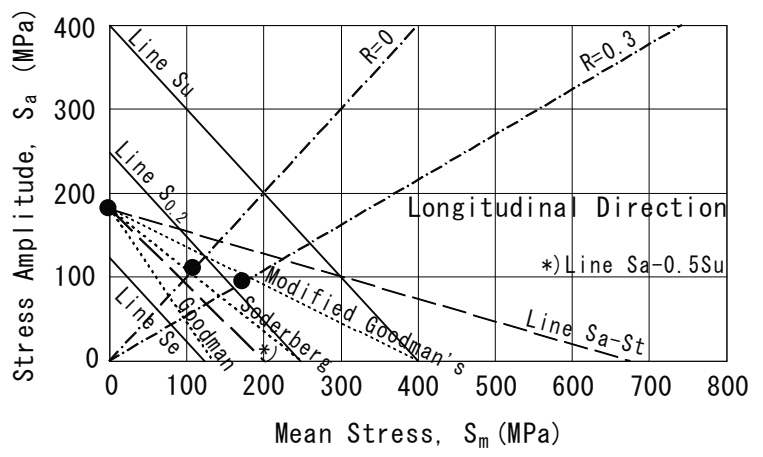

Fig. 6 Endurance limit diagrams (Longitudinal direction).

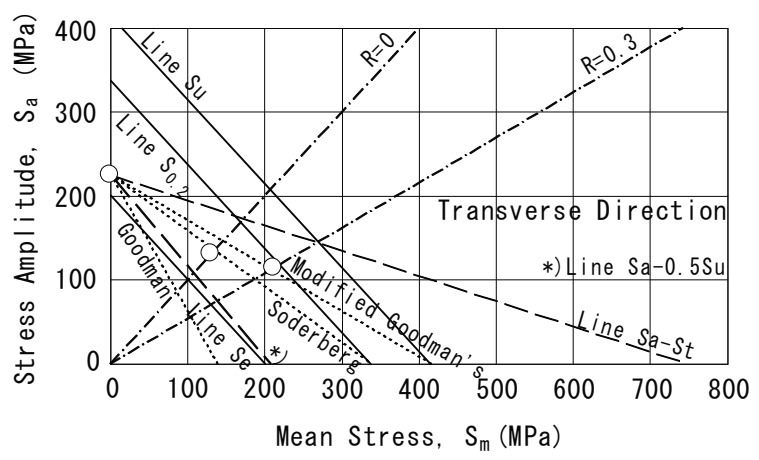

Fig. 7 Endurance limit diagrams (Transverse direction). 
Table 4 Relation between fatigue limit and tensile stress or $0.2 \%$

\begin{tabular}{|c|c|c|c|}
\hline \multicolumn{4}{|c|}{ proof stress } \\
\hline & & \multicolumn{2}{|c|}{ Stress Ratio } \\
\hline & & $R=-1$ & $R=0$ \\
\hline \multicolumn{2}{|c|}{$\begin{array}{l}\text { Carbon steel, Low alloy } \\
\text { steel, Aluminum alloy }{ }^{1)}\end{array}$} & $S_{w}=0.53 S_{u}$ & $S_{w}=0.42 S_{u}$ \\
\hline \multirow{4}{*}{ CP Titanium } & \multirow{2}{*}{ Longitudinal } & $S_{w}=0.45 S_{u}$ & $S_{w}=0.27 S_{u}$ \\
\hline & & $S_{w}=0.73 S_{0.2}$ & $S_{w}=0.44 S_{0.2}$ \\
\hline & \multirow{2}{*}{ Transverse } & $S_{w}=0.54 S_{u}$ & $S_{w}=0.31 S_{u}$ \\
\hline & & $S_{w}=0.67 S_{0.2}$ & $S_{w}=0.39 S_{0.2}$ \\
\hline
\end{tabular}

伝ぱ挙動は，応力集中部近傍の応力分布のみではなく， より広範囲での応力分布により支配されると報告して いる. 一方，工業用純チタン 2 種の $0.2 \%$ 耐力は $900 \mathrm{MPa}$ 級 Ti-6Al-4V 合金の 29（L 方向）～39（T 方向）\%であ り，疲労試験中の荷重が著しく低いので，Ti-6Al-4V 合 金で見受けられるファセット起点の内部破壊が発生す るほどには応力集中部周囲の応力が大きくなく, $10^{7}$ 回 以下では内部破壊が起こらなかったと考えられる.

しかしながら，工業用純チタンでは， $10^{7}$ 回強度を疲 労限度としても，Ti-6Al-4V 合金とは異なり修正 Goodman 則による予測が危険側となった. Table 4 に疲 労限度 $S_{w}$ と引張強度 $S_{u}$ または $0.2 \%$ 耐力 $S_{0.2}$ との関係を 示す. 工業用純チタンでは, 竹内ら ${ }^{1)}$ により報告されて いる炭素鋼，低合金鋼，アルミニウム合金における表面 破壊の場合の疲労限度 $S_{w}$ と引張強度 $S_{u}$ の関係は成立し ていないが, 引張強度 $S_{u}$ に代わって $0.2 \%$ 耐力 $S_{0.2}$ を用い ると， $R=0$ において類似の関係が成立している.

以上より，工業用純チタンでは，鋼材や Ti-6Al-4V 合 金とは異なり, 疲労強度が引張強度以上に $0.2 \%$ 耐力の影 響を受けるので, L 方向と $\mathrm{T}$ 方向の両方向で, 実験点が Soderberg 線図〜修正 Goodman 線図の範囲に位置したと 考えられる. 特に $R=0$ では $S_{0.2}$ を用いる Soderberg 線図 とほぼ同等 (L 方向) かわずかに下回る（T 方向）ため, 平均応力が重愳する設計用の疲労限度としては, Soderberg 線図をそのまま適用できず, 修正ではないオリ ジナルの Goodman 線図か, 少なくとも $S_{a}-0.5 S_{u}$ 線を用い る必要がある。

次に, Fig. 8 に疲労限度 $S_{w}$ と 1-R の関係を両対数グラ フ上に示寸. 図中の直線は次式で与えた。

$$
S_{w}=S_{w, 0} \times(1-R)^{\gamma}
$$

ここで, $S_{w, 0}$ は $R=0$ における疲労限度であり, 指数 $\gamma$ は L 方向では $0.65, \mathrm{~T}$ 方向では 0.68 であった．標準偏差は $\mathrm{L}$ 方向で $7.5 \times 10^{-4}$, $\mathrm{T}$ 方向で $1.2 \times 10^{-3}$ といずれも小さく, 直線で表されている. 竹内ら ${ }^{1)}$ により Ti-6Al-4V 合金で は，900MPa 級は $\gamma=0.68 ， 1100 \mathrm{MPa}$ 級は $\gamma=0.72$ である と示されており，本研究で工業用純チタンに対して得ら れた $\gamma$ も記の報告とほぼ同じ值であった。一方，疲労 下限界 $\Delta K_{t h}$ と 1-R の関係も式(1)と同様な関係が成り立 つと報告されている.

$$
\Delta K_{t h}=\Delta K_{t h, 0} \times(1-R)^{\gamma}
$$

ここで， $\Delta K_{t h, 0}$ は $R=0$ における疲労下限界である. 金尾 $ら^{10)}$ により, 各種構造用鋼では, $1-R=2 \sim 0.2$ の範囲で $\gamma=0.61 \sim 0.74$ となるが, 材料の強度水準や組織との相関 は認められず, 疲労下限界 $\Delta K_{t h}$ を変化させる最大の要因 は応力比であり, 機械的性質や金属組織の寄与は少ない

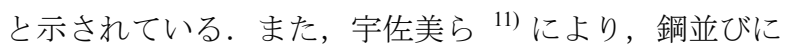
アルミニウム合金やチタン合金などの非鉄金属では, $1-R=6 \sim 1$ の範囲で $\gamma=0.8,1-R=1 \sim 0.4$ の範囲で $\gamma=0.6$ と なり，材料によらず類似の関係が成立していることが示 されている. 本研究で得られた $10^{7}$ 回疲労限度 $S_{w}$ は疲労 き裂進展の下限界 $\Delta K_{t h}$ と応力比効果に対して同様の傾 向を示すといえる.

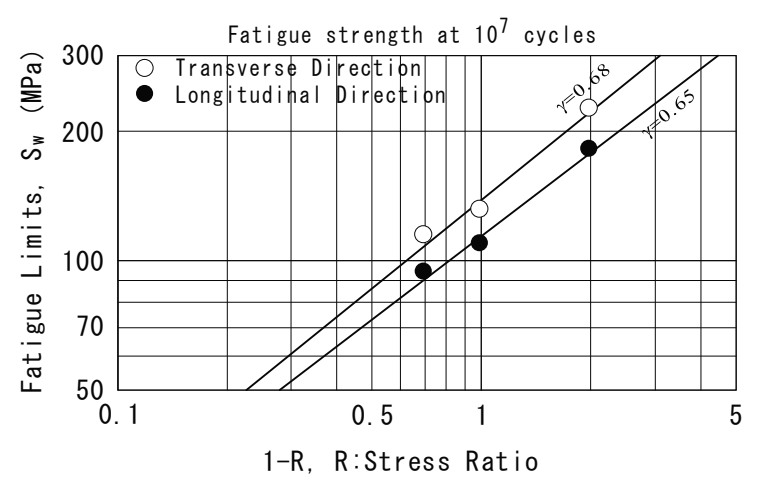

Fig. 8 Relation between fatigue limits $S_{w}$ and stress ratios.

\section{3 応力集中の影響評価}

Fig. 9 に応力集中係数 $K_{t}$ と切欠係数 $K_{f}$ の関係を示寸. $K_{t}=1.00 \sim 1.08$ は線形であると仮定し, $K_{t}=1.08$ の疲労限 度を 1.08 倍した值を $K_{t}=1.00$ の疲労限度として $K_{f}$ を算出 した。一般に, 鋼材, アルミ合金ともに $K_{t} \leqq 2$ 程度まで は $K_{f} \fallingdotseq K_{t}$ に近く, $K_{t} \fallingdotseq 4$ に近づくにつれて次第に飽和し, $\mathrm{T} 6$ 熱処理の $6061 \mathrm{Al}$ 合金 ${ }^{12)}$ では $K_{f} \fallingdotseq 2, \mathrm{C}=0.5 \%$ の炭素 鋼を除く炭素鋼 ${ }^{13)}$ や $\mathrm{H} 112$ 調質の $5083 \mathrm{Al}$ 合金 ${ }^{12)}$ では $K_{f} \fallingdotseq 2.5, \mathrm{C}=0.5 \%$ の中炭素鋼 ${ }^{13)}$ や $\mathrm{O}$ 調質の $5083 \mathrm{Al}$ 合金 12)・T5 熱処理の $6005 \mathrm{CAl}$ 合金 ${ }^{14)}$ では $K_{f} \fallingdotseq 2.5$ 以上であ る. 工業用純チタンは, $\mathrm{L}$ 方向では, $\mathrm{C}=0.5 \%$ の炭素鋼 を除く炭素鋼や H112 調質の 5083Al 合金と同程度，T方

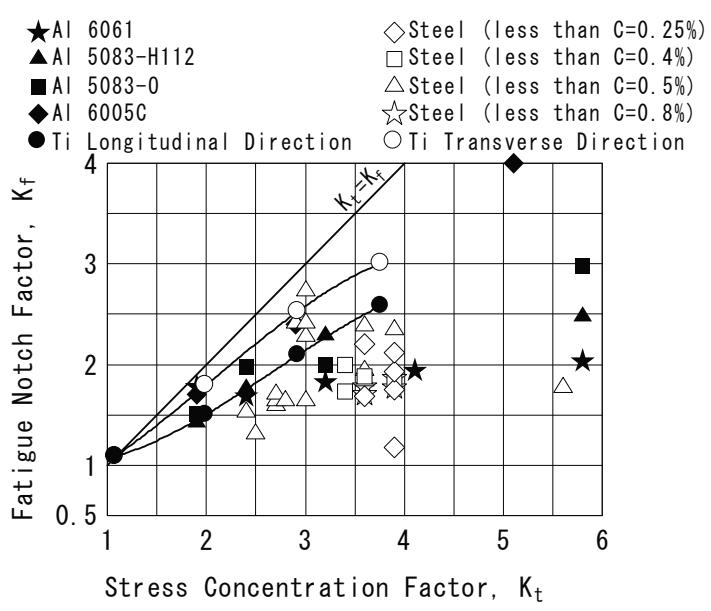

Fig. 9 Relation between stress concentration factor, $K_{t}$, and notch factor, $\left.K_{f .}{ }^{12)} \sim 14\right)$ 
向では, $\mathrm{C}=0.5 \%$ の中炭素鋼や $\mathrm{O}$ 調質の $5083 \mathrm{Al}$ 合金・ $\mathrm{T} 5$ 熱処理の $6005 \mathrm{CAl}$ 合金と同程度であった。

高尾ら ${ }^{15)}$ は，工業用純チタン 1 種熱間圧延棒 JIS $\mathrm{H} 4650 \mathrm{~TB} 270 \mathrm{H}$ を用いた $R=-1$ の引張圧縮疲労試験から, 工業用純チタンでは, き裂発生抵抗が伝ぱ抵抗より大き いため，切欠き感受性は炭素鋼より低いが，停留き裂が なく，一旦き裂が発生すれば，き裂が進展して破壊に至 ると報告している。

Fig. 10 に応力集中係数 $K_{t}$ と疲労限度 $S_{w}$ の関係を示す. このき裂発生限界線図において, 鋼の場合では, $K_{t}=3$ 付 近でき裂進展限界が発生するため, き裂の進展限界曲線 と発生限界曲線の両方を示すものとなるが, 今回の純于 タンの場合では, 評価対象とした $K_{t} \leqq 3.77$ の範囲では, すべて破断に至り，領域 I と領域 III の間に，停留き裂は 発生するが破断には至らない領域 II は確認されなかっ た. 特に $\mathrm{L}$ 方向では, $K_{t}$ の值が比較的小さい $K_{t}=2$ 付近 でのき裂発生限界 (実線) は $K_{f} \fallingdotseq K_{t}$ 線（点線）より $30 \%$ 以上大きくなっている。これは， $K_{t}=2$ 付近でのき裂発生 限界がほぼ $K_{f} \fallingdotseq K_{t}$ 線に等しくなる鋼の傾向とは異なっ ており，K$K_{t}$ により幾何学的に決まる応力集中ほどには疲 労強度が低下しておらず, き裂発生抵抗が大きいことに より切欠きに鈍感であることを示している．これに対し て， $K_{t}=3.77$ における $S_{w}$ の值は， $K_{t}=2.93$ における $S_{w}$ の 值より $20 \%$ ぼ低下しており， $S_{w}$ の值が飽和して頭打ち になっているとはいえない. これは， $K_{t}=3.0$ を超えても 疲労強度が低下し続けていることを表しており， $K_{t} \leqq$ 3.77 の範囲では, 停留き裂がないことにより切欠きに敏 感であると考えられる. なお，溶接構造用圧延鋼材 JIS SM490B に近い低炭素鋼である船級規格船体構造用高張 力鋼板 KE36（AH36 相当）での応力集中係数 $K_{t}$ と疲労 限度 $S_{w}$ の関係は, $K_{t}>3$ では $K_{t}$ の影響は小さいと松岡ら により報告されている。 ${ }^{16)}$

Fig. 11 に応力集中係数 $K_{t}$ と切欠き感度係数 $\eta$ の関係を 示す. 切欠き感度係数の比較材は, $\mathrm{S} 45 \mathrm{C}^{17)}, \mathrm{S} 35 \mathrm{C}^{17)}$, S15C $\mathrm{C}^{17)}$ とした. Fig. 11 において, 工業用純チタンの切 欠き感受性は, $K_{t}=2$ 付近では, $\mathrm{L}$ 方向で炭素鋼より小さ く, T 方向では炭素鋼より大きいが, $K_{t}=3.77$ では, L 方 向では，S15C や S35C と同程度， T 方向では，S45C と

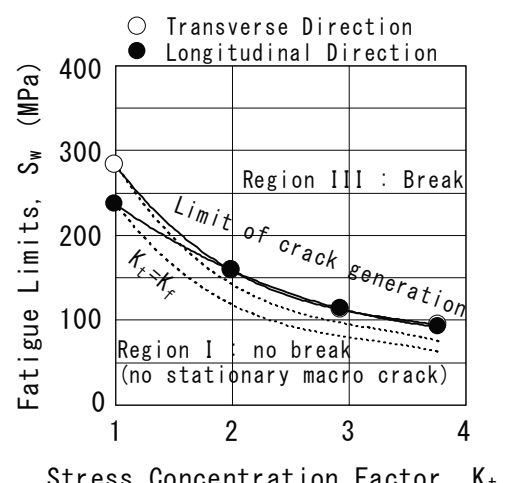

Fig. 10 Crack generation limit diagram.

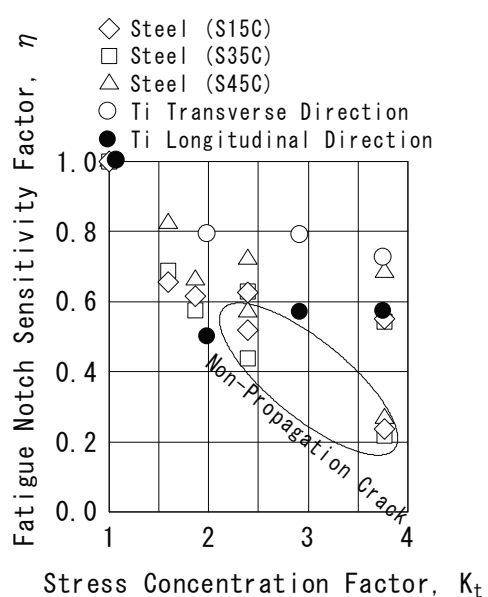

Fig. 11 Relation between stress concentration factor, $K_{t}$, and notch sensitivity factor, $\eta{ }^{17)}$

同程度となった。また，炭素鋼では $K_{t}=2$ 付近から発生す る停留き裂が，純チタンでは確認されなかった。

\section{4 切欠き材の疲労限度線図}

本研究では, 現行の鋼船規則で規定される船舶用軟鋼 に置き換わる新材料として工業用純チタンのうち機械 的強度が最も近い 2 種を評価対象として選定している. 船体構造などを対象とした各継手形状別の推奨疲労設 計強度は，鋼溶接継手とアルミニウム合金溶接継手に関 して既に確立されている。船舶用軟鋼から工業用純于タ ン 2 種への置き換えを想定しているため, 溶接用母材と しての工業用純チタン 2 種の切欠き部が，船舶用軟鋼の 溶接継手に要求される疲労設計強度を満たしているか どうか，本節で検討を行う。

Fig. 12 に切欠き材の L 方向の疲労限度線図を, Fig. 13 に切久き材の $\mathrm{T}$ 方向の疲労限度線図示す.縦軸の切片は, 鋼で提案されている疲労強度設計法に倣い ${ }^{18)}$, 本研究で 対象とした $K_{t}$ の最大值 $K_{t}=3.77$ における $K_{f}$ の值で除した $S_{w} / K_{f}$ (L 万向 : $S_{w} / K_{f 2.581}$, T 方向 $\left.: S_{w} / K_{f 3.006}\right)$ とした. 横 軸の切片は, 平滑材の実験点が $S_{a}-S_{t}$ 線図によく近似する 鋼材では真破断応力 $S_{t}$ が提案されている ${ }^{7)}$ が, 純チタン の場合の平滑材の実験点は Soderberg 線と同じかやや下 回っている. そこで, 横軸の切片を, $S_{0.2}$ とする線と $0.5 S_{u}$ とする線の両方を図中に示した．横軸の切片を $S_{0.2}$ とす る場合危険側の予測となるため, 横軸の切片は $0.5 S_{u}$ 以 下とする必要がある.

溶接止端などに切欠きを有する船舶構造の溶接継手 の疲労強度は, 鋼材は実績が豊富でデータが蓄積されて おり，社団法人日本造船研究協会（現一般社団法人日 本船舶技術研究協会）の第 202 研究部会「海洋構造物の 疲労設計法および溶接部の品質に関する研究」19) などに おいて疲労試験が行われた。この試験結果を元に，松岡 ５２） は解析を行い， $R=0$ の疲労限度を公称応力 $123 \pm$ 26.6MPa と設定した。 2 標準偏差の下限值は $96.4 \mathrm{MPa}$ である.また, International Institute of Welding (IIW) による溶接継手の推奨疲労設計 21) では, 止端研削を行 
わない突合継手の $R=0$ の 200 万回疲労強度（疲労限度 では無い) は，鋼材の場合 $90 \mathrm{MPa}$ である．松岡らの試 験結果を基にした解析值の下限值 $96.4 \mathrm{MPa}$ と IIW の推 奨疲労設計強度 $90 \mathrm{MPa}$ のうち，より安全側である $90 \mathrm{MPa}\left(R=0, S_{m}=45 \mathrm{MPa}, S_{a}=45 \mathrm{MPa}\right)$ を図中に併せて 示す. Fig. 12 と Fig. 13 中に示される純チタンの $S_{w} / K_{f}-0.5 S_{u}$ 線は，推奨疲労設計強度 $90 \mathrm{MPa}$ を上回って いるので，船舶用軟鋼の機械的強度に最も近い工業用純 チタン 2 種による溶接構造物の設計を行う場合, 鋼溶接 構造物と比較して疲労強度を厳しくする必要はないと 言える。

降伏応力 $S_{0.2}$ を応力集中係数 $K_{t}$ で除した曲線と疲労限 度線（き裂の発生限度曲線）との交点は，き裂の進展限

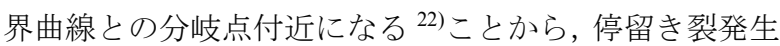
限度として $S_{0.2} / K_{t 3.77}$ 線を疲労限度線図中に併せて記載 した。停留き裂が発生する鋼材では, 縦軸の切片 $S_{w} / K_{f}$ は $K_{t}=3.77$ において $S_{0.2} / K_{t 3.77}$ 線よりかなり上となるため, $R=0$ 線より $S_{m}$ が大きい側で鋼の疲労限度線 (き裂の発生 限度曲線） $S_{w} / K_{f}-S_{t}$ 線と $S_{0.2} / K_{t 3.77}$ 線が一般的に交差する. 一方，純チタンでは $K_{t}=3.77$ において，Fig. 9 で示される とおり切欠係数 $K_{f}$ が大きく, Fig. 10 で示されるとおり $K_{t}=3.0$ を超えても疲労強度が低下し続けている.よって, 純チタンの $S_{w} / K_{f}-0.5 S_{u}$ 線と $S_{0.2} / K_{t 3.77}$ 線との交点は, 鋼材 と比較して $S_{m}$ が小さくなる方向の $R=0$ 線より $S_{m}$ が小さ い側ヘシフトし， $R \geqq 0$ では交点を持たない。このことか らも，純チタンでは， $R \geqq 0$ において停留き裂は発生する が破断には至らない領域は生じないといえる.

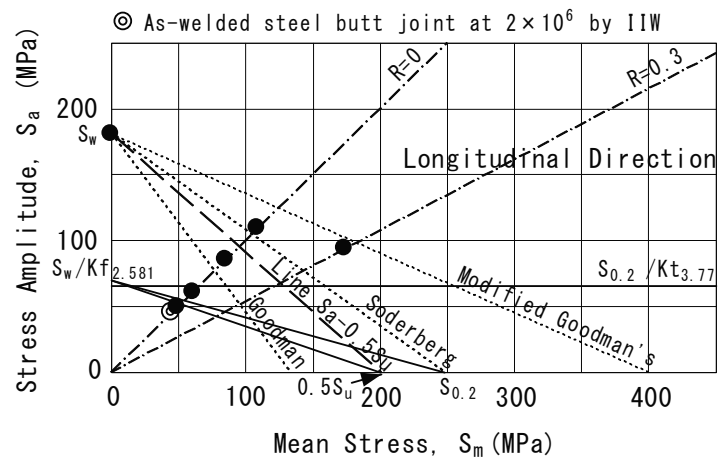

Fig. 12 Endurance limit diagrams (Longitudinal direction).

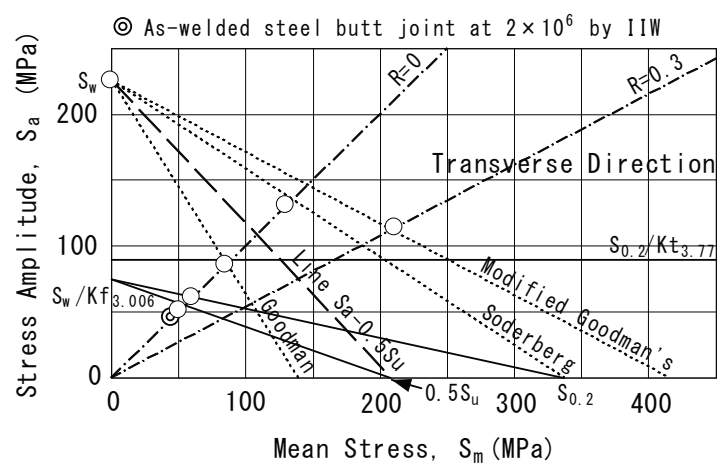

Fig. 13 Endurance limit diagrams (Transverse direction).

\section{4 結 論}

1) 平滑材では $\mathrm{L}$ 方向の疲労限度は $\mathrm{T}$ 方向の疲労限度の 80〜84\%であるが，切欠き材では，L方向の疲労限度 と $\mathrm{T}$ 方向に疲労限度は有意な差がなかった。

2) L 方向と $\mathrm{T}$ 方向の両方向で，実験点が Soderberg 線図 〜修正 Goodman 線図の範囲に位置した. 工業用純于 タンにおいて安全側の設計をするには，少なくとも $S_{a}-0.5 S_{u}$ 線を適用する必要がある.

3) 工業用純チタンの切欠き感受性は, $K_{t}=2$ 付近では, L 方向で炭素鋼より小さく, $\mathrm{T}$ 方向では炭素鋼より大 きいが， $K_{t}=3.77$ では，L方向では，S15C や S35C と 同程度, $\mathrm{T}$ 方向では, $\mathrm{S} 45 \mathrm{C}$ と同程度となった.また, 炭素鋼では $K_{t}=2$ 付近から発生する停留き裂が, 純于 タンでは確認されなかった。

4) 船舶用軟鋼の機械的強度に最も近い工業用純チタン 2 種による溶接構造物の設計を行う場合，鋼溶接構 造物の設計疲労強度が適用できると思われる。

本研究は社団法人（現 一般社団法人）日本チタン協 会との共同研究により実施しました。 また，本研究の立 案に際しご協力を頂きました, 元 海上技術安全研究所 小林佑規氏に厚く御礼を申し上げます。

\section{参 考 文 献}

1) E. Takeuchi, Y. Furuya, N. Nagashima and S. Matsuoka, "Effect of stress ratio on fatigue properties for Ti-6Al-4V alloy", Tetsu-to-hagane, Vol.93, No.4, pp.309-316 (2007).

2) K. Hayashi, S. Nishida and N. Hattori, "Fatigue properties of notched specimens of Ti-6Al-4V alloy", Transactions of the Japan Society of Mechanical Engineers (A), Vol.65, No.638, pp.2080-2085 (1999).

3) T. Iwata and K. Matsuoka, "Fatigue strength of CP grade 2 titanium fillet welded joint for ship structure", Welding in the world, Vol.48, No.7/8, pp.40-47 (2004).

4) Y. Mine, S. Ando, K. Takashima, H. Tonda and Y. Higo, "Crack propagation behavior under cyclic loading in $\alpha$-titanium single crystals", Journal of the Japan Institute of Metals, Vol.61, No.1, pp.41-48 (1997).

5) Y. Mine, S. Ando, H. Tonda, K. Takashima and Y. Higo, "Crystallographic dependence of fatigue crack growth in titanium single crystals", Journal of the Japan Institute of Metals, Vol.62, No.8, pp.708-717 (1998).

6) T. Fujii, K. Morishige, S. Hamada and H. Noguchi, "Fatigue strength characteristics of notched specimens of commercial pure titanium", JSME annual meeting (1), pp.331-332 (2007).

7) Ed. the Society of Materials Science, Japan, "Fatigue design manual", pp.82-84 (1995), Yokendo.

8) K. Takao and K. Kusukawa, "Propagation behavior of small fatigue cracks initiated at the notch in commercially pure titanium", Transactions of the Japan Society of Mechanical Engineers (A), Vol.60, No.570, pp.352-357 (1994).

9) K. Takao and K. Kusukawa, "Fatigue crack initiation behavior in notched member of commercially pure 
titanium", Journal of the Society of Materials Science, Japan, Vol.40, No.458, pp.1422-1427 (1991).

10) M. Kanao, E. Sasaki, A. Ohta and M. Kosuge, "Fatigue crack propagation properties and $\Delta K_{\text {th }}$ for several structural steel plates", Tetsu-to-hagane, Vol.69, No.7, pp.868-873 (1983).

11) S. Usami, "Applications of threshold cyclic-plastic-zone-size criterion to some fatigue limit problems", Proceedings of International Conference of Fatigue Thresholds, Vol.1, pp.205-238 (1981).

12) K. Takeuchi and E. Tanaka, "Fatigue strength of notched aluminum alloy wrought products (part 1)", Sumitomo light metal technical reports, Vol.9, No.4, technical data sheet pp.15-17 (1968).

13) Ed. the Japan Society of Mechanical Engineers, "Design document of the metal materials fatigue strength I", pp.141-142(1982), The Japan Society of Mechanical Engineers.

14) K. Takeuchi, "Fatigue design data and concepts of aluminium structures (10)", Journal of light metal welding \& construction, Vol.33, No.11, pp.556-565 (1995).

15) K. Takao and H. Nishitani, "Fatigue crack initiation and notch sensitivity of commercial purity titanium", Transactions of the Japan Society of Mechanical Engineers (A), Vol.50, No.453, pp.1049-1052 (1984).

16) K. Matsuoka, I. Takahashi, T. Yoshii and E. Fujii, "Influence of residual stress on fatigue strength of non-load-carrying fillet welded joints", Transactions of the Japan Welding Society, Vol.9, No.1, pp.36-42 (1991).

17) N. Noda, H. Nishitani, S. Harada and Y. Takase, "Effect of microstructures on the fatigue strength of notched specimen in ferritic-pearlitic steels", Transactions of the Japan Society of Mechanical Engineers (A), Vol.60, No.575, pp.1517-1523 (1994).

18) H. Ohtaki, "The fatigue strength design method of the machine”, pp.96-97(2007), Nikkan Kogyo Shimbun Ltd. (The Daily Industrial News).

19) $202^{\text {nd }}$ Research Section, "Research report about the fatigue design method for offshore structure and the quality of welded section", (1991), The Shipbuilding Research Association of Japan.

20) K. Matsuoka and E. Fujii, "An evaluation method on fatigue crack initiation life at welded joints in steel structures", Journal of the Society of Naval Architects of Japan, No.178, pp.513-522 (1995).

21) A. F. Hobbacher, "Recommendations for Fatigue Design of Welded Joints and Components $2^{\text {nd }}$ edition", pp.47(2016), Springer.

22) H. Ohtaki, "The fatigue strength design method of the machine", pp.151-152(2007), Nikkan Kogyo Shimbun Ltd. (The Daily Industrial News). 